\title{
K NOVĚ ZJIŠTĚNÝM DŽBÁNOVITÝM OBJEKTŮM NA PÍSKOVCI
}

\author{
FRANTIŠEK GABRIEL - LUCIE KURSOVÁ
}

\begin{abstract}
Abstrakt: Článek navazuje na práci F. Gabriela a K. Knopa (1990). K sedmi džbánovitým objektům vysekaným do pískovcového podloži přidává pět objektů dalšich, které se shoduji se zjistitelnými znaky sedmi předchozich, jsou však poškozeny mladšimi zásahy. Jejich průzkum a výzkum dovoluje jejich funkčni spojení se zásobnicemi.
\end{abstract}

Klíčová slova: džbánovité objekty - zásobnice - piskovcové podloží.

\section{Jug-shaped features newly discovered in sandstone}

Abstract: This article is a follow-up to a study by F. Gabriel and K. Knop (1990). It expands the group of seven jug-shaped features cut into sandstone subsoil with another five that share the same identifiable characteristics. However, they were damaged by more recent interventions. Their research and exploration enabled the identification of the features as storage pits.

Key words: jug-shaped features - storage pit-sandstone subsoil.

\section{Úvod}

V roce 1990 vyšel článek zabývající se otázkami kolem džbánovitých objektů zahloubených do pískovcového podloží (Gabriel-Knop 1990), seznamující odbornou veřejnost s návrhem jejich nové interpretace vylučující poněkud romantické spojení s hladomornami a na základě pokusu vylučující i jejich užívání jako cisteren na vodu (viz i Podroužek 2007). Při srovnání s menšími, ale tvarově podobnými pravěkými a raně středověkými objekty užívanými u nás jako zásobnice na obilí (Kudrnáč 1970, 89-96; Beranová-Kubáček 2010, 107-111) a s mladšími, rovněž tvarově podobnými, avšak přibližně stejně velkými objekty z období novověku (Kunz 1951) se jako nejpravděpodobnější funkce nabízí zásobnice pro ukládání obilí. Je až překvapivé, že řada prací věnujících se dějinám zemědělství na našem území přehlédla a dosud přehlíží doklad této středověké a novověké technologie ukládání obilovin, doložené hloubením do půdního podloží již $\mathrm{v}$ pravěku a raném středověku. Na málo zmínek o zemních jámách v našich středověkých a raně novověkých písemných pramenech si stěžuje L. Kunz $(1965,155)$ a s povzdechem uvádí první zmínku o nich až na přelomu 15. a 16. století. Dnes je můžeme jednoznačně prokázat ve formě džbánovitých objektů vysekaných do pískovcového podloží a naznačit i jejich pozdější užití.

\section{Nově zjištěné džbánovité objekty}

Ze sedmi objektů uvedených v článku F. Gabriela-K. Knopa (1990), jejichž hloubka činila 3,90-8,28 m, maximální průměr byl v rozmezí 1,81-4,26 m a minimální průměr horního ústí hrdla mezi 1,05-1,21 m (Gabriel-Knop 1990, 263), je objekt na Poustevnickém kameni (Einsiedlestein) u Sloupu druhotně narušen od jihu prosekaným schodištěm vedoucím ke dnu objektu (Gabriel-Knop 1990, 266; obr. 1). Při průzkumech sídel Kozlov-Chlum (k. ú. Olešnice u Turnova, okr. Semily), Valdštejn (k. ú. Mašov u Turnova, okr. Semily), Kvítkov (k. ú. Kvítkov, okr. Česká Lípa), Houska (k. ú. Houska, okr. Česká Lípa) a Úštěk (k. ú. Úštěk, okr. Litoměřice) bylo zjištěno dalších pět objektů vysekaných v pískovcovém podloží později narušených mladšími stavebními aktivitami do té míry, že byla změněna jejich forma a původní funkce, a tím došlo i k nesprávné interpretaci.

Nejvýraznější zásah znamenala těžba skalního bloku na sídle Kozlov-Chlum (obr. 2), která zachovala pouze dolní část objektu $(280 \mathrm{~cm})$, zatímco větší horní část (ca 4,46 m) odtěžila. Zařazení mezi džbánovité objekty dnes dovoluje vedle odhadované výšky $7,26 \mathrm{~m}$ pouze kruhový půdorys (průměr ca $3,10 \mathrm{~m}$ ), mírné zúžení $\mathrm{k}$ horní hraně zachované části (průměr $2,30 \mathrm{~m}$ ) 


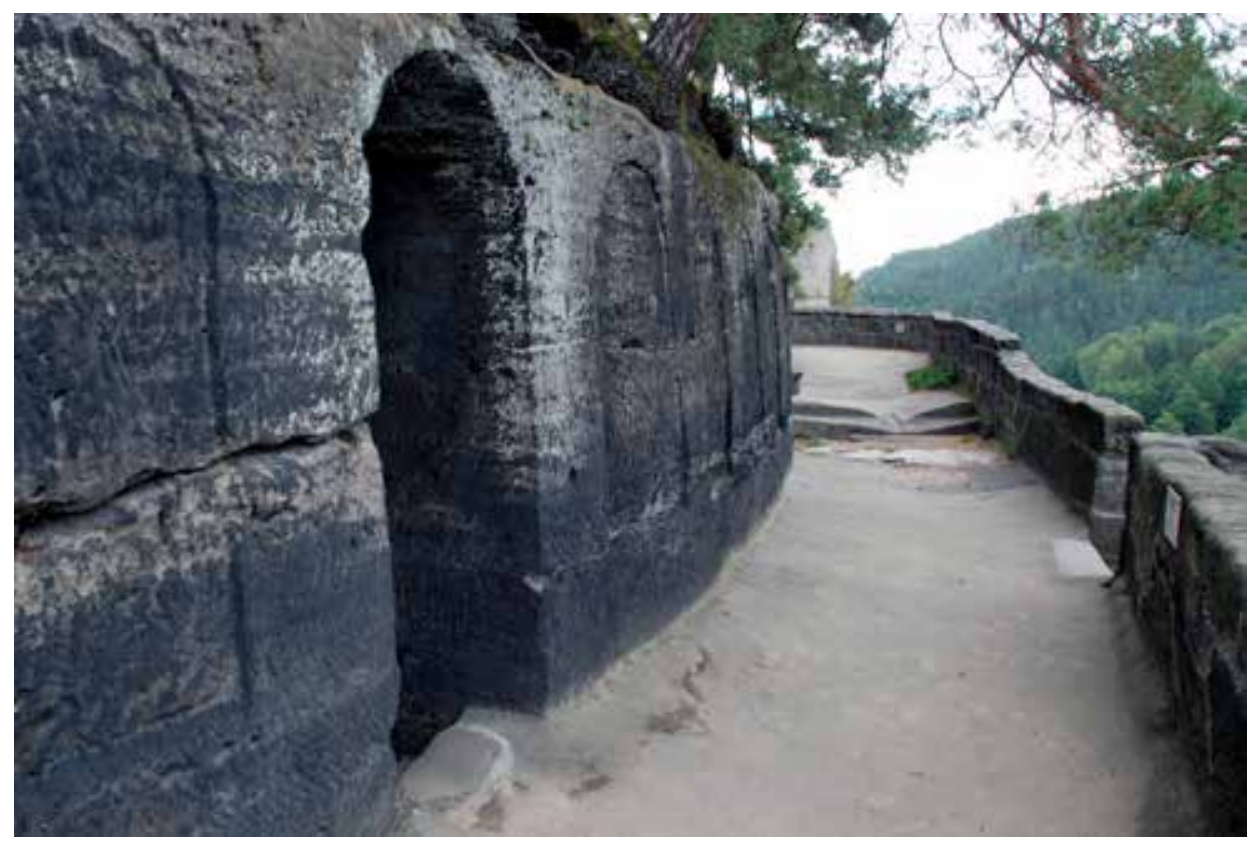

Obr. 1. Poustevnický kámen, k. ú. Sloup v Čechách. Vstup z jižní strany do džbánovitého objektu z mladší terasy s kř́ǐ̌ovou cestou. Foto L. Kursová.

Abb. 1. Einsiedlerstein, Katastergebiet Sloup in Böhmen. Eingang von der Südseite in das krugförmige Objekt von der jüngeren Terrasse mit Kreuzweg. Foto L. Kursová.

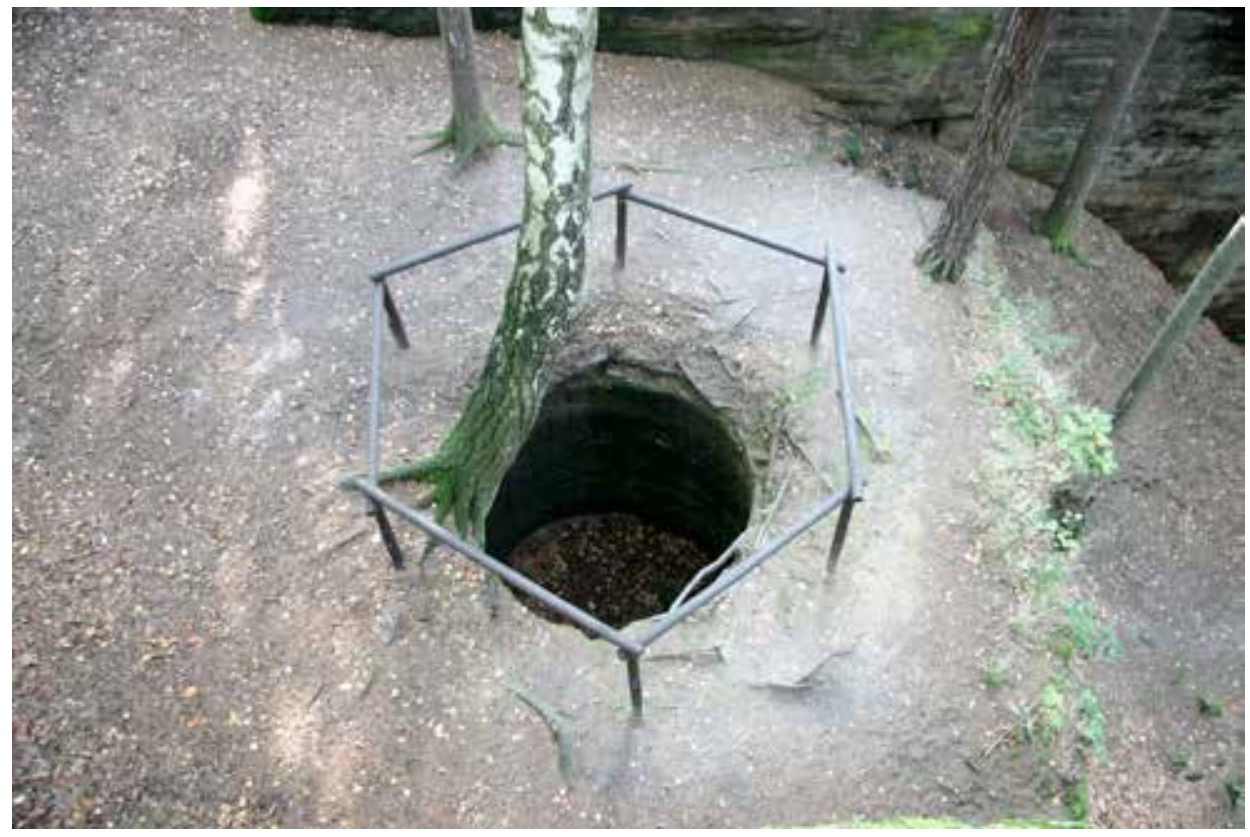

Obr. 2. Sídlo Kozlov-Chlum, k. ú. Olešnice u Turnova. Dochovaný relikt džbánovitého objektu po odtěžení horní partie. Foto L. Kursová.

Abb. 2. Burgsitz Kozlov-Chlum, Katastergebiet Olešnice bei Turnov. Erhaltenes Relikt eines krugartigen Objektes nach Abtragung der oberen Partie. Foto L. Kursová. 


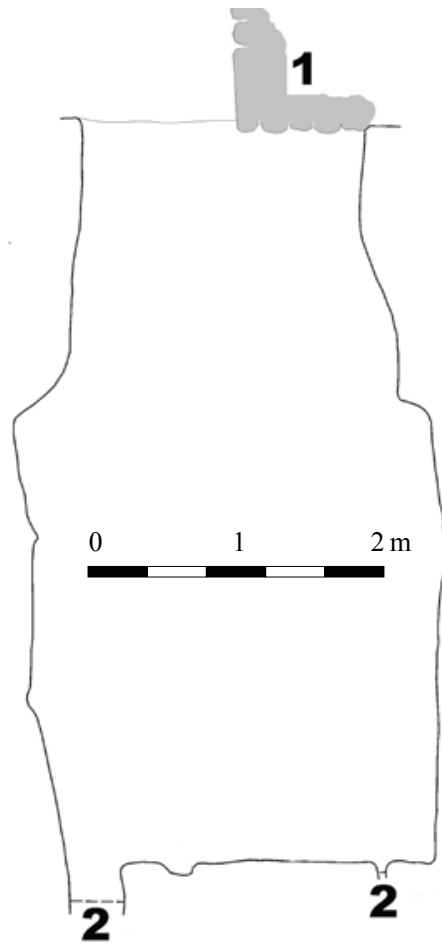

Obr. 3. Hrad Valdštejn, k. ú. Pelešany. Profil džbánovitého objektu na 1. díle hradu. 1 - zdivo klasicistní budovy, 2 - pukliny s hlinitou výplní. Kresba podle Hartman-Prostředník 2004, obr. 6, úprava F. Gabriel.

Abb. 3. Burg Valdštejn, Katastergebiet Pelešany. Profildarstellung des krugartigen Objektes im ersten Burgteil. 1 Mauerwerk des klassizistischen Gebäudes, 2 - mit Lehm ausgefüllte Risse. Zeichnung nach Hartman-Prostředník 2004, Abb. 6, bearbeitet von F. Gabriel.

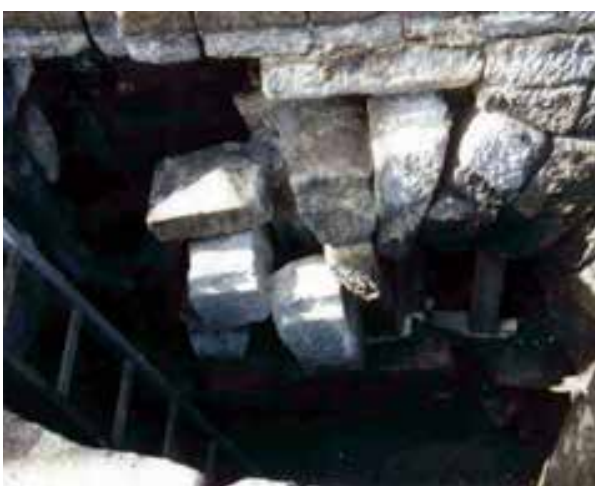

Obr. 4. Hrad Valdštejn, k. ú. Pelešany. Rozpadlá odlehčovací klenba nad horním ústím hrdla džbánovitého objektu na 1. díle hradu. Foto podle NZ Hrad Valdštejn 09-10/2002, $10 / 2003$, foto 4 .

Abb. 4. Burg Valdštejn, Katastergebiet Pelešany. Eingestürztes Entlastungsgewölbe über der oberen Halsmündung des krugartigen Objektes im ersten Burgteil. Foto nach NZ Hrad Valdštejn 09-10/2002, 10/2003, Foto 4. a uvedené rozměry pohybující se v metrice ostatních, zcela dochovaných džbánovitých objektů (Gabriel-Knop 1990, 263).

Na sídle Valdštejn evidují džbánovitý objekt již starší práce (např. Sedláček 1895, 58) a je prezentován i v práci F. Gabriela a K. Knopa $(1990,266)$. Vracíme-li se k tomuto sídlu, pak z toho důvodu, že zde oprava klasicistního domu, stojícího na prvním díle hradu, odkryla další, značně porušený objekt sledovaného typu (NZ 2003; obr. 3). Stěny druhého džbánovitého objektu, zkoumaného a publikovaného P. Hartmanem a J. Prostř́edníkem (2004), pravděpodobně narušil opad skalního podloží a jeho hrdlo asi poškodilo zakládání zmíněného klasicistního domu (obr. 4). Jak naznačují nejspíše středověké nebo raně novověké rytiny na opadlé stěně, došlo k prvnímu z narušení asi ještě $\mathrm{v}$ době užívání objektu a nelze vyloučit ani poškození stěn již při jeho hloubení v pískovcovém podloží, prot’atém několika puklinami a spárami. Druhé poškození souvisí pravděpodobně se stavbou domu, při jehož založení byla nestabilní hlinitá výplň uvedeného objektu nejspíše překlenuta odlehčovacím obloukem. Obě poškození setřela původní tvar zahloubené části a znemožnila užití metriky, která je dána současným nepravidelným tvarem o hloubce $5,40 \mathrm{~m}$, maximálním průměrem při dně $3,09 \mathrm{~m}$ a minimálním průměrem horního ústí hrdla $1,85 \mathrm{~m}$ (Hartman-Prostředník 2004).

Další džbánovitý objekt zjistila revize reliktů středověkého sídla v Kvítkově. Rovněž tento objekt poškodila mladší aktivita spočívající v hloubení studny, která džbánovitý objekt využila a jeho stěny pojala do svého obvodu (obr. 5). Dnes částečně zasypanou studnu protíná široká puklina, která nepochybně procházela i džbánovitým objektem, a bylo třeba ji ve styku se stěnami a dnem vyplnit a objekt tak uzavřít. Materiál a struktura výplně se nedochovaly a nelze je ani odhadnout. Další narušení přineslo odtěžení hrdla objektu na jihovýchodní straně od pukliny. Zůstal tak zachován pouze segment kruhového hrdla (obr. 6), z jehož horního ústí odhadujeme poloměr kružnice na $1 \mathrm{~m}$. Maximální šířka se pravděpodobně pohybovala kolem $3,50 \mathrm{~m}$ a hloubka nejspíše překračovala $6 \mathrm{~m}$.

Zbylé dva objekty postihl stejný osud jako objekt na Poustevnickém kameni u Sloupu. 


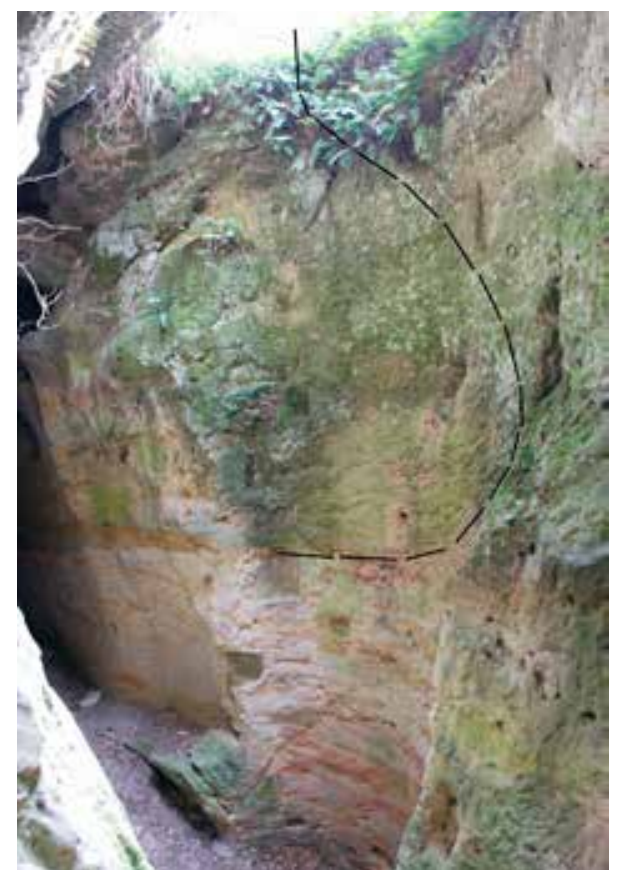

Obr. 5. Hrad Kvítkov, k. ú. Kvítkov. Západní stěna studny se stopami džbánovitého objektu s odstraněným hrdlem. Pohled od severu. Foto L. Kursová.

Abb. 5. Burg Kvítkov, Katastergebiet Kvítkov. Westwand des Brunnens mit Spuren eines krugartigen Objektes mit entferntem Hals. Blick von Norden. Foto L. Kursová.

Na hradě Houska byl vysekán džbánovitý objekt pod nádvořím hradního jádra. Jeho hloubku neznáme, nebot' prostor ve spodním ústí hrdla uzavřela po druhotném prosekání schodiště klenba, sklenutá $\mathrm{z}$ kamene na maltu (obr. 7), a povrch pískovcového podloží, kam se objekt svým horním ústím hrdla otevíral, dnes kryje dlažba. Hloubka objektu od klenby k podlaze po odkrytí dlažby (obr. 8) je 4,05 m a šířka v maximálním zjištěném rozpětí činí 3,13 m. Doplníme-li při rekonstrukci výšku hrdla o $1 \mathrm{~m}$, tedy přibližně na $5,05 \mathrm{~m}$, leží uvedené rozměry v metrice celých džbánovitých objektů (Gabriel-Knop 1990, 263).

Druhý džbánovitý objekt zjistilo ohledání suterénu při archeologickém výzkumu hradu Úštěku v roce 2013. K jeho interpretaci přispěl následný archeologický výzkum $\mathrm{v}$ roce 2016, prováděný při opravě severního křídla hradu, pod kterým se objekt nachází. Majitel hradu nechal objekt vysekat na nádvoří při severní hradební zdi. Zdá se, že později, nejspíše někdy na přelomu 15. a 16. století, proběhla

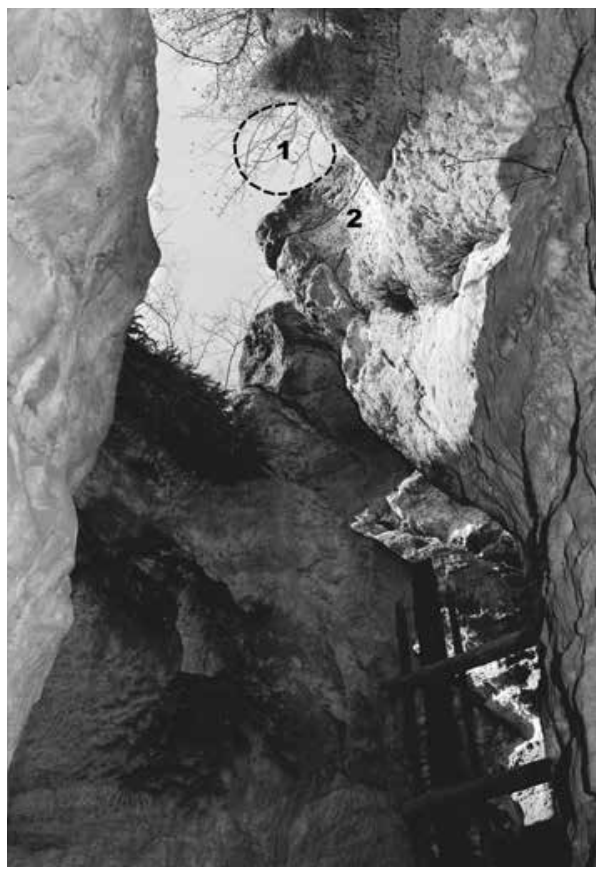

Obr. 6. Hrad Kvítkov, k. ú. Kvítkov. Relikt hrdla džbánovitého objektu. 1 - domodelovaný relikt horního ústí hrdla, 2 - stěna hrdla. Pohled od jihu. Foto R. Kursa.

Abb. 6. Burg Kvítkov, Katastergebiet Kvítkov. Relikt des Halses des krugartigen Objektes. 1 - vervollständigtes Relikt der oberen Halsmündung, 2 - Wand des Halses. Blick von Süden. Foto R. Kursa.

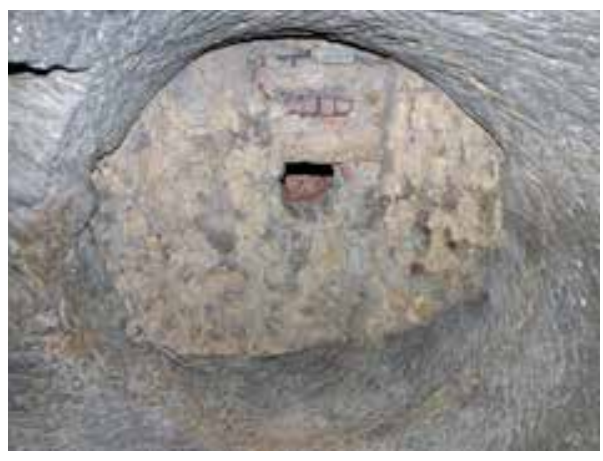

Obr. 7. Hrad Houska, k. ú. Houska. Sklenutí ve spodním ústí hrdla džbánovitého objektu narušeného nově vysekaným sklepem. Foto I. Peřina.

Abb. 7. Burg Houska, Katastergebiet Houska. Einwölbung in der unteren Halsmündung des krugartigen Objektes, das durch einen neu herausgehauenen Keller gestört wurde. Foto I. Peřina.

rozsáhlá přestavba hradu, se kterou spojujeme založení jeho severního kř́ílla nad objektem při severní obvodové hradbě. Současně s budováním novostavby pravděpodobně došlo 


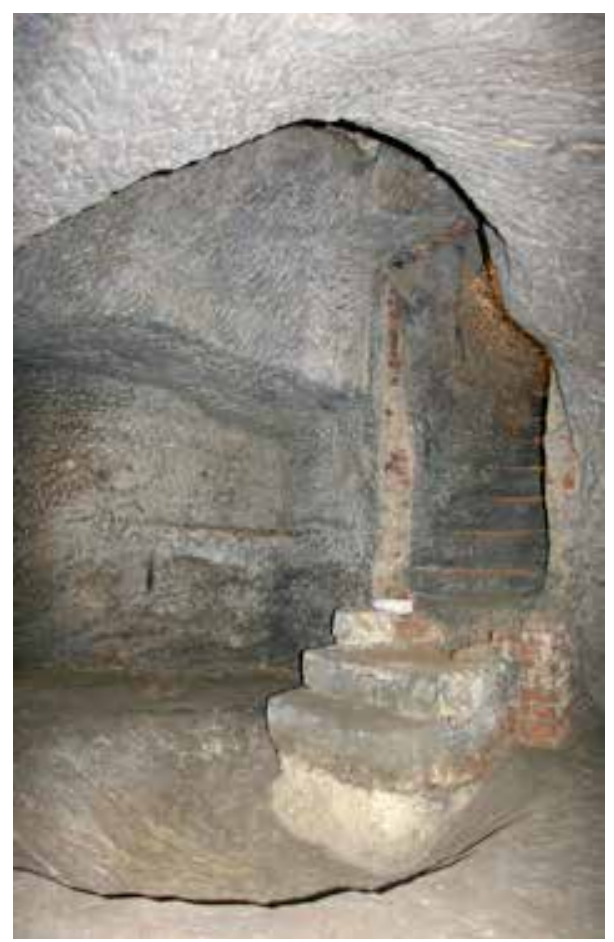

Obr. 8. Hrad Houska, k. ú. Houska. Podlaha džbánovitého objektu po zpřístupnění schodištěm, rozšířením do podoby sklepa a po odstranění výplně s dlažbou v průběhu výzkumu. Foto I. Peřina.

Abb. 8. Burg Houska, Katastergebiet Houska. Fußboden des krugartigen Objektes nachdem es mit einer Treppe zugänglich gemacht, zu einem Keller vergrößert und die Verfüllung mit der Pflasterung bei der Grabung beseitigt wurde. Foto I. Peřina. k zasypání tohoto džbánovitého objektu. Horní ústí jeho hrdla překryla přibližně $1 \mathrm{~m}$ mocná jednorázová navážka, navyšující celý dvůr, a rovněž podlahy místností novostavby. Podlahu místnosti, pod kterou džbánovitý objekt ústil, tvořila mazanina bílé vápenné malty. Relikty maltové podlahy, odkryté archeologickým výzkumem, naznačují polygonální závěr její západní strany (obr. 9). Místnost pokračovala podél hradby až k východní zdi současné úpravy kř́idla. Někdy v období novověku započalo pod touto zdí hloubení schodiště, klesajícího západním směrem, se záměrem vytvořit prrístup do plánovaného sklepa. Při jeho sekání kameníci pravděpodobně narazili na výplň objektu tvořenou sypkým materiálem. Práce pokračovala jejím vybráním do úrovně podlahy hloubeného sklepa, a to včetně propadlé výplně z hrdla objektu, vystupujícího nad plánovaný strop suterénu. Propad výplně hrdla objektu způsobil i sesuv jednorázové navážky nadloží a nejspíše i narušení podlahy z maltové mazaniny. Nepotřebný otvor uzavřela při spodním ústí hrdla kamenná klenba na maltu a z místnosti nad sklepem ji zaplnila mladší výplň. Tato situace se včetně maltové podlahy dochovala pod mladší vrstvou zásypu, chráněna položením dřevěné podlahy, sloužící v přízemí domu až do roku 2015. Její stržení si vyžádalo zahájení opravy dochované části severního křídla. Tato stavební aktivita města Úštěku, současného majitele hradu, vyvolala potřebu záchranného archeologického výzkumu, který zajistil správce památky, Městský úřad v Úštěku. ${ }^{1}$

Záchranný archeologický výzkum odkryl podlahu z utažené maltové mazaniny, deformovanou ukloněním a „potrháním“ při okraji propadlého zásypu (obr. 9). Výzkum, který hloubkově překročil rozsah novodobé stavební aktivity, limitovaly technické podmínky a postup stavebních prací. Tyto faktory neumožnily dokončení výkopu nad horním ústím hrdla. Horní ústí a výplň hrdla nad rubem klenby tak zůstaly překryty. Naopak se podařilo odkrýt spodní partii. Objekt zde vyplňovala řada rychle se stř́ídajících a zjevně i propojených hlinitopísčitých vrstev béžové barvy s drobnými pískovcovými kameny a fragmenty stavební keramiky (dlaždice $17,0 \times 17,0 \times 4,5-5,0 \mathrm{~cm}$ ), přisedajícími k vysekané pískovcové stěně (obr. 10, 11). Výplň vykazuje jednoznačné stopy sypání, nejspíše jednorázového, které proběhlo v době ukončení funkce objektu.

Hloubku objektu, stejně jako u většiny ostatních džbánovitých objektů předkládaných nově v tomto článku, pouze odhadujeme podle nepřímého měření na $3,90 \mathrm{~m}$. S ohledem na měřitelnou výšku vrcholnice klenby ode dna $(3,38 \mathrm{~m})$ nelze vyloučit i hloubku větší. Měřený průměr dna $(3,18 \mathrm{~m})$ se mírně rozšiřuje k maximálnímu průměru výdutě $(3,36 \mathrm{~m})$. Šířku hrdla neznáme. I při odhadu hloubky a změřených průměrech leží rozměry v rozsahu metriky zcela dochovaných džbánovitých objektů (Gabriel-Knop 1990, 263).

1 Za umožnění výzkumu v provedeném rozsahu děkujeme Městskému úřadu v Úštěku a toleranci dělníků, provádějících zde stavební práce. 


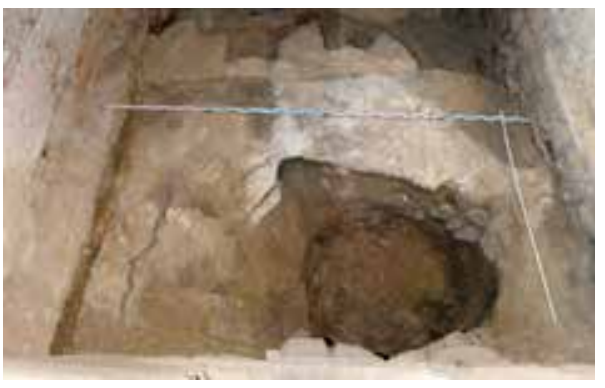

Obr. 9. Hrad Úštěk, k. ú. Úštěk. Mazaninová podlaha z bílé vápenné malty s ,potrhanými““ plochami nad propadlou výplní džbánovitého objektu. Foto L. Kursová.

Abb. 9. Burg Úštěk, Katastergebiet Úštěk. Lehm-Kalkmörtel-Fußboden mit ,zerrissenen“ Flächen über der eingefallenen Verfüllung des krugartigen Objektes. Foto L. Kursová.
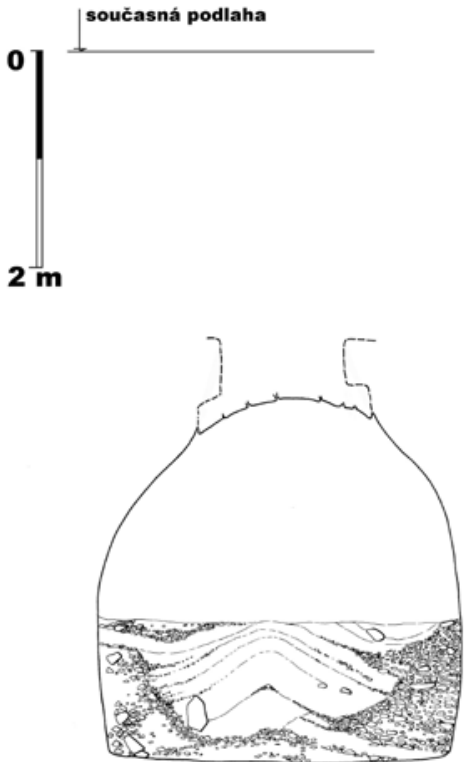

Obr. 10. Hrad Úštěk, k. ú. Úštěk. Profil džbánovitého objektu s vrstvami výplně a modelem nepř́ístupné části (čárkovaně). Kresba L. Kursová, B. Linhartová.

Abb. 10. Burg Úštěk, Katastergebiet Úštěk. Profildarstellung des krugartigen Objektes mit Verfüllungsschichten und einem Modell des unzugänglichen Teils (gestrichelt). Zeichnung L. Kursová, B. Linhartová.

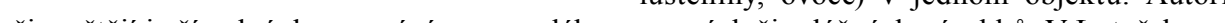
připouštějí i př́ípadné deponování masa, mléka a masných či mléčných výrobků. V Lotyšsku se údajně v takovýchto objektech vedle uzených ryb skladoval i jantar. Problém je třeba rozdělit na možnost společného ukládání různých druhů obilovin, případně i s luštěninami, a využití pro ukládání masa nebo jiných živočišných druhů potravin.

2 Vedle jílu užívaného jako izolace proti vodě v základovém zdivu historických sklepů (Gabriel-Kursová 2014, 416-417) a tvrdé kletované omítky, známé z mediteránní oblasti, další omazávku zabraňující průsaku vody - ve stř̌edověku dostupnou - neznáme. 


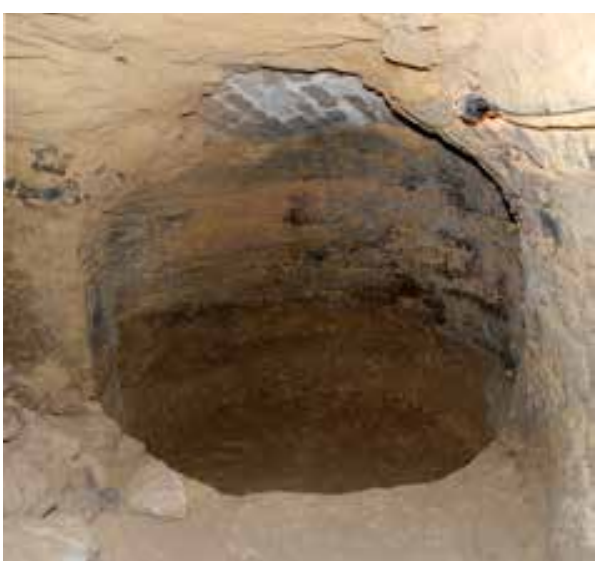

Obr. 11. Hrad Úštěk, k. ú. Úštěk. Relikty džbánovitého objektu po vybrání výplně pod úrovní podlahy. Foto L. Kursová.

Abb. 11. Burg Úštěk, Katastergebiet Úštěk. Relikte des krugartigen Objektes nach Aushebung der Verfüllung bis unter Fußbodenniveau. Foto L. Kursová.
Společné skladování různých druhů obilovin $\mathrm{v}$ jednom objektu předpokládá jejich oddělování v obalech nebo pomocí přepážek (Beranová-Kubačák 2010, 110). S ukládáním obilovin do obalů však nesouhlasí J. Kudrnáč $(1959,479-450 ; 1970,95)$ a své negativní stanovisko zdůvodňuje požadavkem, který formuloval J. Krieger, „aby se obili k doški̊m [obkladu stěn] dobře ušlapalo, aby se pak príliš neslehlo a nevzniklo mnoho prázdného mista" (Kunz 1951, 222). Mezi obaly by ovšem „prázdná místa“ vznikla a vzduch by umožňoval obilovinám nežádoucí klíčení.

Rovněž funkci sledovaných objektů jako „sklepư“ pro ukládání jiných než sypkých potravin, především masa a mléčných výrobků na průběžnou spotřebu, můžeme přijmout pouze stěží. Důvodem je jejich úzké hrdlo, které v případě funkce „sklepa“ postrádá smysl a zbytečně znesnadňuje prístup k zásobám. $\mathrm{Na}$ horním ústí hrdla objektů vysekaných v pís-

kovcovém podloží by se navíc nepochybně zachovaly stopy dřevěného záklopu, který by byl nezbytnou ochranou proti hlodavcům a hmyzu. Nejpravděpodobnější stopu v podobě polodrážky kolem horního okraje ústí však nezjišt’ujeme. Zdá se tedy, že hrdlo sloužilo k uzavření zásypem, vyžadujícím zaplnění celého objektu.

Jinou možnost ovšem nabízí druhotné užití sledovaných objektů po skončení původní funkce. Jako provizorium, nejspíše ovšem pouze na krátkou dobu, mohly džbánovité objekty sloužit i k ukládání masa, mléka, masných a mléčných výrobků. Uživatel objektu by je nejspíše spouštěl v koších nebo ve vacích zavěšených na provaze někam pod hrdlo. Záklop, pravděpodobně dřevěná deska, mohl být rovněž provizorní, a tak horní okraj hrdla zůstal bez úprav původní formy, jež byla určena pro ochranu obilovin. Jednoznačný doklad takového užití tedy lze jen stěží nalézt. Snad jistým náznakem, vycházejícím z pravidla, že funkce se často opakuje podobným užitím, je pozdější zpř́ístupnění objektu vysekáním schodiště a rozšířením depozitního prostoru na hradě Houska. Podobně i některé z bývalých obilních jam zahloubených do sprašové hlíny jsou dnes spojeny úzkými průkopy v úrovni dna s vinnými sklepy (Kunz 1951, 224). Zdá se, že úpravu zde vyvolala právě nepraktičnost užívání objektu jako sklepa, kterou pozdější úpravy odstranily. V př́ípadě Poustevnického kamene ve Sloupu se pravděpodobně jednalo o jiný důvod zpřístupnění (Gabriel-Podroužek-Zahradník 2001,9) a na úštěckém hradě asi došlo k narušení staršího objektu náhodou, ačkoliv povědomí o jeho existenci a poloze v době hloubení sklepa vyloučit nemůžeme.

Pro všechny zcela zachované zahloubené části džbánovitých objektů je typický průměr horního ústí hrdla v rozmezí 1,05-1,21 m. Z nově zjištěných objektů se dochoval pouze segment kružnice horního ústí hrdla na sídle Kvítkov, z nějž dovozujeme poloměr ca $1,10 \mathrm{~m}$. Objekt tak rozšiřuje počet džbánovitých objektů s uvedeným rozpětím průměrů horního ústí. Pro ostatní nově zjištěné objekty toto prověřené rozpětí průměru naopak využíváme při modelování vertikálního profilu. Zdá se, že na rozdíl od metriky ostatních částí objektů je průměr horního ústí hrdla svými rozměry zavazující. Důvodem snad mohl být na jedné straně dostatečný prostor pro pohodlný průlez člověka, který na druhé straně minimalizoval co nejmenší objem zásypu, omezujícího přístup vzduchu a únik kysličníku uhličitého produkovaného skladovaným obilím. Nepřekvapí proto, že při rekognoskaci terénu severovýchodně od Chumary, severně nad údolím Inau (Karačajevsko-čerkeská republika, Ruská federace), téměř 3000 km východně od střední Evropy, jsme naměřili průměr horního ústí hrdla džbánovitého objektu v pískovcovém podloží 
$0,80 \mathrm{~m}$, tedy jen o málo menší než rozpětí těchto rozměrů džbánovitých objektů v pískovcovém podloží u nás a stejných rozměrů, jaké uvádí L. Kunz $(1951,224)$ ve sprašových hlínách jižní Moravy $(0,70-0,80 \mathrm{~m})$. Je škoda, že metrika středověkých džbánovitých objektů z ostatních oblastí světa, jak je naznačuje L. Kunz (1965), nejsou snáze dostupné, nebot' hrdlo pravděpodobně představovalo významnou část objektu chránícího uložené obilí.

Součástí ochrany obilí, jak uvádějí i podle historických záznamů a starší literatury L. Kunz (1951, 222-224), J. Kudrnáč (1970, 91-96) a M. Beranová a A. Kubačák (2010, 109-110), bylo vypálení a obložení stěn došky, které se ovšem v objektech vysekaných do pískovce zř̌ejmě neužívalo. Při plnění objektu se obilí dusalo až k spodnímu ústí hrdla. Z nejrůznějších uzavření a zatížení došky, hlínou, kameny, dřevěným křížem, ledkem (pravděpodobně dusičnanem draselným, $\left.\mathrm{KNO}_{3}\right)$ či nehašeným vápnem $(\mathrm{CaO})$ představuje zvláště cenný záznam článek $\mathrm{B}$. Němcové z roku 1857 uvádějící, že „hrdlo pak vyplňuje se vrstvou popele, vrstvou pisku, a to tak až po sám vrch“ (Kunz 1951, 224; Kudrnáč 1970, 96). Důležitý se zdá právě popel, zjištěný i při archeologických výzkumech v Rumunsku (Kudrnáč 1970, 95). Jemný popel má význam pro ochranu proti hmyzu, jehož dýchání zajišt’uje systém vzdušnic, které popel ucpe a tím pronikající hmyz udusí.

\section{Závěr}

Ze všech zpráv, počínaje zápisy z antického světa a konče zprávami z 18. století, i z etnografických a archeologických pozorování zaznamenaných v literatuře vyplývá, že džbánovité objekty, uváděné pod různými názvy, ${ }^{3}$ byly dlouhodobě od neolitu až po 19 . století užívány a prověřovány na rozsáhlém území Evropy, Asie i Afriky (Kunz 1965). Jejich funkce zřejmě určovala po celou dobu uživání jejich podobu. Odlišují se od sebe spíše velikostí s trendem postupného zvětšování a způsoby ukládání a zajištovaní obilí. Oba faktory nepochybně ovlivnilo i podloží, do kterého byly zahloubeny. Jedním z nich, jak je patrné, bylo i podloží pískovcové.

\section{Literatura}

BERANOVÁ, M.-KUBAČÁK, A., 2010: Dějiny zemědělství v Čechách a na Moravě. Praha.

GABRIEL, F.-KNOP, K., 1990: K interpretaci džbánovitých objektů na pískovci - Zur Interpretation krugartiger Objekte im Sandstein, AH 15, 261-274.

GABRIEL, F.-KURSOVÁ, L., 2014: Zakládání zděných hradních staveb v severních Čechách - Die Fundamentlegung bei gemauerten Burgbauten in Nordböhmen, AH 39, 411-419.

GABRIEL, F.-PODROUŽEK, K.-ZAHRADNÍK, P., 2001: Skalní sídlo u Sloupu - Die Einsiedlerstein bei Sloup. Praha.

HARTMAN, P.-PROSTŘEDNÍK, J., 2004: Záchranný výzkum středověké zásobnice na hradě Valdštej$\mathrm{nu}$ - Archäologische Rettungsausgrabungen einer mittelalterlichen Vorratskammer auf der Burg Valdštejn, Z Českého ráje a Podkrkonoší 17, 9-34.

KUDRNÁČ, J., 1959: Staroslovanské obilnářství v českých zemích - Die altslawische Getreidewirtschaft in der böhmischen Ländern, PA XLIX, 478-498.

- 1970: Klučov staroslovanské hradiště ve středních Čechách - Klučov ein altslawischer Burgwall in Mittelböhmen. Praha.

KUNZ, L., 1951: Obilní jámy a sýpky v Čejkovicích u Hodonína, Český lid XXXVIII, 221-226.

- 1965: Historické zprávy o zemních silech v zóně mediteránního a eurosibiřského obilnářství - Getreidegruben ind der eurosibirischen und mediterrannen Zone, ČMMZ 50, 143-182.

NZ 2003: Nálezová zpráva Hrad Valdštejn 09-10/2002, 10/2003, rkp. ulož. v Muzeu Českého ráje v Turnově. PODROUŽEK, K., 2007: Cisterny na vodu v pískovci Experiment na hradě Helfenburku u Úštěka. In: Minulosti Českého Švýcarska IV (Belisová, N., ed.), 90-109. Krásná Lípa.

SEDLÁČEK, A., 1895: Hrady zámky a tvrze Království českého 10. Praha.

3 Za starý slovanský termín považoval L. Niederle označení ,žitna jama, žitnica“ (Kudrnáč 1970, 90). B. Němcová nazývá v polovině 19. století tyto objekty „zemnice“ (Kunz 1951, 224) a v etnografické a archeologické literatuře se setkáme s pojmenováním zásobní jáma, obilní jáma, zemní silo nebo obilnice. 


\section{Zusammenfassung}

\section{Neue Erkenntnisse über krugartige Objekte in Sandstein}

Der vorliegende Beitrag knüpft an die Arbeit von F. Gabriel-K. Knop (1990) an, in welcher krugartigen Objekten, die in einen Sandsteinunterboden gehauen wurden, die Funktion von Getreidevorratsspeichern zugeschrieben werden. Sieben der aufgeführten Objekte verbindet die Form und ihre Metrik mit einer Tiefe von 3,90-8,28 m, einem maximalen Durchmesser von 1,81-4,26 m und einem Mindestdurchmesser der oberen Halsmündung von 1,05-1,21 m. In dem Objekt Einsiedlerstein bei Sloup wird von den Verfassern aufgeführt, dass der Eingang zum Objektboden sekundär durchgehauen wurde (Gabriel-Knop 1990, 266; Abb. 1). Bei den Untersuchungen der Burgsitze Kozlov-Chlum (Katastergebiet Olešnice bei Turnov, Bezirk Semily), Valdštejn (Katastergebiet Mašov bei Turnov, Bezirk Semily), Kvítkov (Katastergebiet Kvítkov, Bezirk Česká Lípa), Houska (Katastergebiet Houska, Bezirk Česká Lípa) und Úštěk (Katastergebiet Úštěk, Bezirk Litoměřice) wurden weitere fünf in einen Sandsteinunterboden gehauene Objekte entdeckt, die später durch jüngere Bauaktivitäten in einem solchen Maß gestört wurden, dass sich ihre Form, ursprüngliche Funktion und damit auch ihre spätere Interpretation geändert hat. Die Gruppe der neu registrierten in einen Sandsteinunterboden gehauhenen Objekte entspricht der früher schon abgegrenzten Metrik und bestätigt ihre Verwendung zum langfristigen Lagern von Getreide als Reserve bei einem Saatgutmangel. Darauf deutet der typische Durchmesser der oberen Halsmündung hin, der es einer Person erlaubt, bequem durchzuklettern und gleichzeitig ein Entweichen des Kohlendioxids minimiert, das bei der Lagerung von Getreide produziert wurde und dessen Keimung verhinderte. Laut den Quellen aus dem 18. und 19. Jahrhundert hat man das an der unteren Halsmündung aufgeschüttete Getreide mit Strohmatten, Steinen und mit Salpeter oder ungelöschtem Kalk angereichertem Lehm abgedichtet. Eine Aufzeichnung von B. Němcová aus dem Jahr 1857 besagt, dass der Hals mit Sand- und Ascheschichten verfüllt war. Asche verstopft die Tracheen von Insekten, was deren Erstickung zur Folge hat und so ihre Ausbreitung im Getreide verhindert. Aus allen Berichten seit der Antike bis in das 18. Jahrhundert sowie aus ethnographischen und archäologischen Beobachtungen ergibt sich, dass krugartige Objekte ab dem Neolithikum bis ins 19. Jahrhundert in den ausgedehnten Gebieten Europas, Asiens und Afrikas als Getreidevorratsspeicher genutzt wurden. Ihrer Form nach sind sie offenbar über ihre gesamte Verwendungsdauer identisch. Sie unterscheiden sich eher durch ihre jeweilige Größe und durch die Vorgehensweisen bei der sicheren Lagerung des Getreides voneinander. Beide Faktoren wurden zweifellos auch durch den Unterboden beeinflusst, in dem sie ausgehoben wurden. Bei einem von ihnen handelte es sich auch um einen Sandsteinboden.

doc. PhDr. František Gabriel, Ph.D., Katedra archeologie Filozofické fakulty Západočeské univerzity v Plzni, Sedláčkova 15, 30614 Plzeň, Česká republika,pu-uvpd-cl@volny.cz

PhDr. Lucie Kursová, Regionální muzeum v Teplicích, Zámecké náměstí 517/14, 41501 Teplice, Česká republika,kursova.rmt@seznam.cz 
